\title{
The science and art of neurology
}

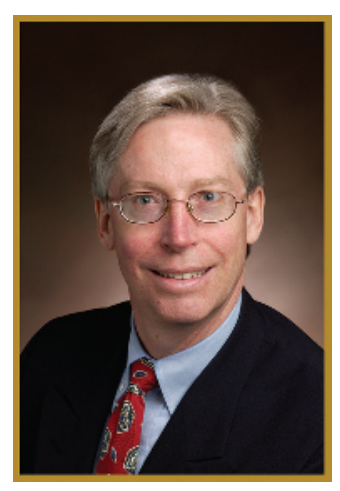
"In examining disease, we gain wisdom about anatomy and physiology and biology. In examining the person with
disease, we gain wisdom about life."

_Oliver Sacks, The Man Who Mistook His Wife for a Hat

W

hile science is primarily data-driven, art is steeped in emotion and humanity. Both science and art embrace ideas and offer a means of investigation. This issue of Neurology ${ }^{\circledR}$ Clinical Practice features articles that reinforce the importance of science and art in the practice of neurology, particularly in the patient/physician encounter.

End-of-life decision-making is challenging for patients, their loved ones, and physicians. Seeber et al. present a qualitative ethical analysis of Dutch neurologists' reports on how they involve families of critically ill patients in end-of-life decision-making. The neurologists surveyed perceived the surrogates not only as informants about the patients' views and participants in decisions about care but also as sufferers themselves who need to be supported in coping with their potential loss. An accompanying editorial by Hwang and Bernat discusses the role of "protective paternalism" in end-of-life decision-making.

Management of patients who have undergone extensive and escalating diagnostic tests for medically unexplained symptoms can be challenging. Lockhart and SatyaMurti describe the utility of symptom validity tests (SVTs), often used by neuropsychologists, to assess for possible symptom exaggeration. The authors conclude that judicious use of SVTs can inform the need for further testing and guide the clinician toward the most appropriate interventions and referrals.

We welcome your feedback on these articles and seek suggestions for future topics of particular interest to neurologists in practice.
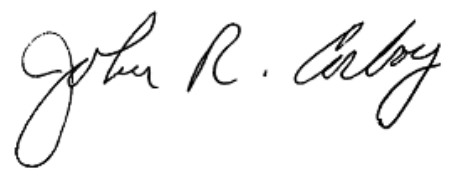

John R. Corboy, MD, FAAN 


\title{
Neurology ${ }^{\circ}$ Clinical Practice
}

\author{
The science and art of neurology \\ Neurol Clin Pract 2015;5;1 \\ DOI 10.1212/CPJ.0000000000000137
}

This information is current as of February 16, 2015

\section{Updated Information \&}

Services

Permissions \& Licensing

Reprints including high resolution figures, can be found at:

http://cp.neurology.org/content/5/1/1.full.html

Information about reproducing this article in parts (figures,tables) or in its entirety can be found online at:

http://cp.neurology.org/misc/about.xhtml\#permissions

Information about ordering reprints can be found online:

http://cp.neurology.org/misc/addir.xhtml\#reprintsus

Neurol Clin Pract is an official journal of the American Academy of Neurology. Published continuously since 2011, it is now a bimonthly with 6 issues per year. Copyright (C) 2015 American Academy of Neurology. All rights reserved. Print ISSN: 2163-0402. Online ISSN: 2163-0933.

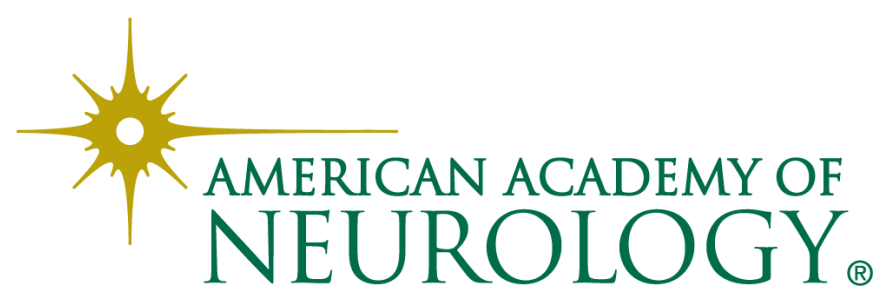

